$\mathrm{JH}$ lus Quia lustum is licensed under a Creative Commons. Attribution 4.0 Intemational License. Which Permits unrestricted use, distrubution, and reproduction in any medium, provided the original work is property cited

\title{
Prinsip Pembuktian Sederhana dalam Permohonan Penundaan Kewajiban Pembayaran Utang*
}

\author{
Devi Andani dan Wiwin Budi Pratiwi \\ Fakultas Hukum Universitas Janabadra Yogyakarta Indonesia \\ Jln. Tentara Rakyat Mataram No. 55-57 Yogyakarta 55231 Indonesia \\ Jln. Timoho II No. 40 Yogyakarta Indonesia \\ devi_andani@janabadra.ac.id; wiwin_budi_p@janabadra.ac.id
}

Received: 30 November 2020; Accepted: 30 Juni 2021; Published: 25 Agustus 2021

DOI: 10.20885/iustum.vol28.iss2.art9

\begin{abstract}
This study aims to determine firstly, the application of simple evidenciary in the application for Postponement of Debt Payment Obligations (PKPU) and secondly, the comparison of the concept of simple evidenciary in PKPU. The research method used is normative legal research, data is collected by means of literature studies and documents written descriptively and analyzed qualitatively. The results of this study show that first, simple evidenciary provision in Article 8 paragraph (4) in conjunction with Article 2 paragraph (1) of the Bankruptcy Law and PKPU, regulates that simple evidenciary applies to applications for bankruptcy statements. Whereas in the PKPU petition, in fact the Bankruptcy Law and PKPU do not require the application of simple evidenciary which states that the petition for a declaration of bankruptcy must be granted if there are facts or circumstances that are simply proven that the requirements for bankruptcy are declared. Second, although the Bankruptcy Law and PKPU do not regulate the principle of simple proof that can be applied in a PKPU application, judges can apply the simple evidenciary principle by taking into account the principles of simple, fast, and low-cost justice and the objectives of the Bankruptcy Law and PKPU can be achieved.
\end{abstract}

Key Words:Bankruptcy; creditor; debtor; simple evidenciary; postponement of debt repayment obligations

\section{Abstrak}

Studi ini bertujuan untuk mengetahui, pertama, pemberlakuan pembuktian sederhana dalam permohonan Penundaan Kewajiban Pembayaran Utang (PKPU), dan kedua, perbandingan konsep pembuktian sederhana dalam PKPU. Metode penelitian yang digunakan yaitu tipologi penelitian hukum normatif, data dikumpulkan dengan cara studi pustaka dan dokumen yang dituliskan secara deskriptif dan dianalisa secara kualitatif. Hasil studi ini menyimpulkan, pertama, pembuktian sederhana yang terdapat dalam Pasal 8 ayat (4) jo Pasal 2 ayat (1) UU Kepailitan dan PKPU, mengatur pembuktian sederhana berlaku terhadap permohonan pernyataan pailit. Sedangkan dalam permohonan PKPU, sebenarnya UU Kepailitan dan PKPU tidak megharuskan penerapan pembuktian sederhana yang menyatakan bahwa permohonan pernyataan pailit harus dikabulkan apabila terdapat fakta atau keadaan yang terbukti secara sederhana bahwa persyaratan untuk dinyatakan pailit. Kedua, meskipun UU kepailitan dan PKPU tidak mengatur asas pembuktian secara sederhana dapat diterapkan dalam permohonan PKPU, namun hakim dapat menerapkan asas pembuktian sederhana tersebut dengan memperhatikan asas peradilan sederhana, cepat, dan biaya ringan serta tujuan dari UU kepailitan dan PKPU dapat tercapai.

Kata-kata Kunci: Debitor; kepailitan; kreditor; pembuktian sederhana; penundaan kewajiban pembayaran utang

* Hibah Penelitian Dosen Pemula Kementerian Riset dan Teknologi / Badan Riset dan Inovasi Nasional 2020 


\section{Pendahuluan}

Pailit menurut Undang-Undang Nomor 37 Tahun 2004 tentang Kepailitan dan Penundaan Kewajiban Pembayaran Utang (selanjutnya disebut UU Kepailitan dan PKPU), kepailitan didefinisikan sebagai sita umum atas semua kekayaan Debitor Pailit yang pengurusan dan pemberesannya dilakukan oleh Kurator di bawah pengawasan Hakim Pengawas. Menurut Michael Murray dan Harris Jonson, tujuan hukum kepailitan didasari oleh prinsip pari pasu pro rata partem (equal sharing) sebagai prinsip hukum terutama dalam kepailitan. Berdasarkan prinsip pari pasu pro rata partem, tujuan dari kepailitan di desain untuk mengatur prosedur pembayaran utang debitor yang tidak mampu membayar utangnya yang dilakukan secara adil, berimbang, dan tertib serta menjamin bahwa para kreditor akan menerima pembagian yang berimbang dan layak dari asset debitor. ${ }^{1}$ Berdasasarkan hal tersebut, maka tujuan kepailitan adalah untuk membagi harta debitor pailit kepada para kreditornya sebagai bentuk pelunasan utang debitor kepada para kreditor, dengan kata lain bahwa debitor tidak dapat melanjutkan usahanya lagi.

PKPU dimaksudkan untuk mencapai perdamaian antara debitor dengan para kreditornya sehingga debitor dapat terus melanjutkan usahanya. Tujuan PKPU adalah untuk memungkinkan seorang debitor meneruskan usahanya meskipun ada kesukaran pembayaran dan untuk menghindari kepailitan. ${ }^{2}$ Permohonan PKPU diajukan oleh debitor atau kreditor atas debitor yang tidak dapat melanjutkan membayar utang-utangnya yang sudah jatuh waktu dan dapat ditagih. Permohonan PKPU diajukan ke Pengadilan Niaga tempat kedudukan debitor yang ditandatangani oleh pemohon dan advokatnya, yang disertai dengan daftar yang memuat sifat, jumlah piutang dan utang debitor beserta surat bukti secukupnya. ${ }^{3}$ Pengajuan PKPU oleh debitor dilatarbelakangi oleh beberapa faktor, yaitu: sebagai upaya mencegah kepailitan; debitor tetap dapat melangsungkan kegiatan usaha; dan PKPU mempunyai manfaat waktu, ekonomis, dan yuridis. ${ }^{4}$

\footnotetext{
${ }^{1}$ Elyta Ras Ginting, Hukum Kepailitan: Teori Kepailitan, Cetakan Pertama, Sinar Grafika, Jakarta, 2018, hlm. 10

2 Rahayu Hartini, Hukum Kepailitan, Cetakan Pertama, UMM Press, Malang, 2007, hlm. 37

${ }^{3}$ Undang-Undang Nomor 37 Tahun 2004 tentang Kepailitan dan Penundaan Kewajiban Pembayaran Utang

${ }^{4}$ R. Anton Suyatno, Pemanfaatan Penundaan Kewajiban Pembayaran Utang Sebagai Upaya Mencegah Kepailitan, Cetakan Pertama, Kencana Prenada Media Group, Jakarta, 2012, hlm. 7
} 
Berdasakan hal tersebut, maka debitor lebih condong untuk mengajukan permohonan PKPU daripada proses kepailitan. Pasal 2 ayat (1) UU Kepailitan dan PKPU diatur mengenai syarat kepailitan dengan pembuktian sederhana yaitu debitor mempunyai dua atau lebih kreditor dan tidak membayar lunas sedikitnya satu utang yang telah jatuh waktu dan dapat ditagih. Jadi jika syarat kepailitan dapat dibuktikan secara sederhana, maka hakim pengawas harus menyatakan pailit bagi debitor, tidak melihat apakah debitor dalam keadaan solvent atau insolvensi. Salah satunya adalah ketika Pengadilan Niaga memutus pailit PT Telekomunikasi Selular Tbk. Yang diajukan oleh PT. Prima Jaya Informatika, yang kemudian pada 14 September 2012 melalui No. 48/PAILIT/2012/PN. NIAGA/JKT.PST diputus pailit. ${ }^{5}$ Lalu pailit terhadap PT Asuransi Jiwa Manulife Indonesia yang dimohonkan oleh PT Dharmala Sakti Sejahtera, yang kemudian pada 13 Juni 2000 melalui Putusan No. 10/Pailit/2002/PN.Niaga.JKT diputus pailit. ${ }^{6}$ Selanjutnya pailit terhadap PT Prudential Life Assurance yang dimohonkan oleh Lee Boon Siong, yang kemudian 23 April 2004 melalui Putusan Pengadilan Niaga Jakarta Pusat No. 13/Pailit/2004/PN.Niaga.JKS.PST diputus pailit.7 Putusan pailit terhadap PT Telekomunikasi Selular Tbk, PT Asuransi Jiwa Manulife, dan PT Prudential Life Assurance memiliki nilai aktiva lebih besar dari pasiva. Ketentuan tersebut menunjukkan bahwa, syarat-syarat debitor untuk dapat dinyatakan pailit oleh pengadilan sangat sederhana. Ketentuan persyaratan permohonan pailit memudahkan debitor dinyatakan pailit, walaupun sebenarnya dalam keadaan solven. Oleh karena itu dikatakan bahwa UU Kepailitan dan PKPU, lebih berpihak kepada kreditor. ${ }^{8}$ Lalu pengajuan PKPU oleh debitor atau kreditor, apakah berlaku pula prinsip pembuktian sederhana mengingat dampak positif PKPU daripada kepailitan.

5 Maruli Simalago, "Inkonsistensi Persyaratan Permohonan Pailit Dihubungkan dengan Asas Kelangsungan Usaha (Going Concern) dalam Undang-Undang No. 37 Tahun 2004 tentang Kepailitan dan Penundaan Kewajiban Pembayaran Utang", Jurnal Syiar Hukum, Vol. 15, No. 1, Juni 2017, hlm 59

6 Annisa Chaula Rahayu, Herman Susetyo, Paramita Prananingtyas, "Putusan Pailit Atas Perusahaan Asuransi dan Akibat Hukumnya di Indonesia (Kajian Yuridis Atas Putusan No. 10/Pailit/2002/PN.JKT.PST dan Putusan MA No. 021 /K/N/2002”, Jurnal Diponegoro Law Review, Vol 1, No. 2, 2013, hlm. 9

7 Amelia, "Tinjauan Yuridis Terhadap Pembatalan Putusan Pailit Atas Perusahaan Asuransi (Studi Kasus PT Prudential Life Assurance melawan Lee Roon Siong)", Tesis, Universitas Tarumanegara, 2018, hlm. 44

${ }^{8}$ Doni Budiono, "Analisis Pengaturan Hukum Acara Kepailitan dan Penundaan Kewajiban Pembayaran Utang”, Jurnal Hukum Acara Perdata, Vol. 4, No. 2, Juli-Desember 2018, hlm 116 


\section{Rumusan Masalah}

Berdasarkan uraian yang telah dipaparkan pada latar belakang masalah di atas, maka disusun rumusan masalah, yaitu: pertama, bagaimana pemberlakuan pembuktian sederhana dalam permohonan penundaan kewajiban pembayaran utang? Kedua, bagaimana perbandingan konsep pembuktian sederhana dalam kepailitan dan permohonan penundan kewajiban pembayaran utang?

\section{Tujuan Penelitian}

Setiap penelitian dan penulisan ilmiah mempunyai tujuan yang ingin dicapai dengan dilakukannya penelitian tersebut. Oleh karena itu, tujuan dilakukannya penelitian ini yaitu: pertama, memahami dan manganalisis terhadap pemberlakuan pembuktian sederhana dalam permohonan penundaan kewajiban pembayaran utang. Kedua, memahami dan menganalisis perbandingan konsep pembuktian sederhana dalam kepailitan dan permohonan penundaan kewajiban pembayaran utang.

\section{Metode Penelitian}

Penelitian ini termasuk jenis penelitian kualitatif dengan mengikuti tipologi penelitian hukum normatif. Tipe penelitian yang digunakan dalam penelitian ini adalah yuridis normatif. Metode pendekatan yang digunakan adalah pendekatan konseptual (conceptual approach), pendekatan perundang-undangan (statute approach), pendekatan analitis (analytical approach) dan pendekatan kasus (case approach). Pendekatan konseptual yang megacu pada pendapat para ahli/doktrin terhadap pembuktian sederhana dalam permohonan penundaan kewajiban pembayaran utang (PKPU). Pendekatan perundang-undangan untuk mengetahui pembuktian sederhana dalam permohonan penundaan kewajiban pembayaran utang (PKPU). Pendekatan analitis untuk menelaah makna istilah hukum yang digunakan dalam praktik hukum dan juga untuk menelaah pengertian, asas, kaidah dan konsep hukum. Pendekatan kasus dilakukan dengan cara menelaah kasus-kasus dan putusan Pengadilan Niaga mengenai penundaan kewajiban pembayaran utang (PKPU) antara lain pailit PT Telekomunikasi Selular Tbk melalui putusan No. 48/PAILIT/2012/PN.NIAGA/JKT.PST, pailit terhadap PT Asuransi Jiwa Manulife Indonesia melalui Putusan No. 10/Pailit/2002/PN. 
Niaga.JKT, dan pailit terhadap PT Prudential Life Assurance melalui putusan No.13/Pailit/2004/PN.Niaga.JKS.PST.

Sumber bahan hukum yang digunakan adalah bahan hukum primer sebagai bahan hukum utama serta bahan hukum sekunder dan tersier sebagai pendukung. Sumber bahan hukum yang digunakan dalam penelitian ini antara lain :

a. Bahan Hukum Primer, merupakan bahan hukum yang mempunyai kekuatan mengikat secara yuridis, yaitu Undang-Undang Nomor 37 Tahun 2004 tentang Kepailitan dan Penundaan Kewajiban Pembayaran Utang, Undang-Undang Nomor 21 Tahun 2011 tentang Otoritas Jasa Keuangan, Undang-Undang Nomor 40 Tahun 2007 tentang Perseroan Terbatas, Kitab Undang Undang Hukum Perdata (KUH Perdata), pailit PT Telekomunikasi Selular Tbk melalui putusan No. 48/PAILIT/2012/PN.NIAGA/JKT.PST, pailit terhadap PT Asuransi Jiwa Manulife Indonesia melalui Putusan No. 10/Pailit/2002/PN. Niaga.JKT, dan pailit terhadap PT Prudential Life Assurance melalui putusan No.13/Pailit/2004/PN.Niaga.JKS.PST.

b. Bahan Hukum Sekunder, merupakan bahan hukum yang tidak mempunyai kekuatan mengikat secara yuridis, yaitu buku, skripsi, tesis, disertasi, dan jurnal hukum.

c. Bahan Hukum Tersier terdiri dari bahan-bahan hukum yang dapat memberi petunjuk dan kejelasan terhadap bahan hukum primer maupun bahan hukum sekunder, yaitu berupa kamus hukum dan ensiklopedia.

Metode pengumpulan bahan hukum yang dilakukan dalam penelitian ini meliputi studi pustaka dan studi dokumen. Data yang diperoleh dianalisa yang dituliskan secara deskriptif dan dianalisa secara kualitatif.

\section{Hasil Penelitian dan Pembahasan}

\section{Pembuktian Sederhana dalam Permohonan Penundaan Kewajiban Pembayaran Utang (PKPU)}

Syarat permohonan putusan pailit dapat diberikan oleh pengadilan niaga dalam lingkungan peradilan umum sesuai dengan Pasal 2 ayat (1) UndangUndang Nomor 37 Tahun 2004 tentang Kepailitan dan Penundaan Kewajiban Pembayaran Utang (selanjutnya disebut UU Kepailitan dan PKPU) yaitu debitor 
yang mempunyai dua atau lebih Kreditor dan tidak membayar lunas sedikitnya satu utang yang telah jatuh waktu dan dapat ditagih, dinyatakan pailit dengan putusan Pengadilan, baik atas permohonannya sendiri maupun atas permohonan satu atau lebih kreditornya. Permohonan pailit tersebut harus dikabulkan jika terdapat fakta atau keadaan yang terbukti secara sederhana bahwa persyaratan untuk dinyatakan pailit. 9

Pembuktian sederhana dalam memutuskan permohonan pailit terdapat dalam Faillissementsverordening, Undang-Undang Nomor 4 Tahun 1998 tentang Penetapan Peraturan Pemerintah Pengganti Undang-Undang Nomor 1 Tahun 1998 tentang Perubahan atas Undang-Undang tentang Kepailitan menjadi Undang-Undang (selanjutnya disebut Undang-Undang Nomor 4 Tahun 1998, UU Kepailitan dan PKPU. Faillissementsverordening menentukan pembuktian sederhana dilakukan terhadap adanya peristiwa-peristiwa atau keadaan-keadaan yang menunjukkan debitor berada dalam keadaan telah berhenti membayar utang-utangnya, dan jika permohonan pernyataan pailit diajukan oleh seorang kreditor, maka terdapat hak penagihan dari kreditor ini. Pendapat ini berkembang berkaitan dengan pembuktian sederhana pada masa Faillissementsverordening antara lain pembuktian tentang debitor dalam keadaan berhenti membayar harus dilakukan secara sederhana (summier). Artinya, pengadilan di dalam memeriksa permohonan pernyataan pailit tidak perlu terikat dengan sistem pembuktian dan alat-alat bukti yang ditentukan dalam hukum acara perdata. Contoh penerapan pembuktian sederhana pada masa berlakunya Faillissementsverordening adalah bukti dan pengakuan debitor yang menyatakan debitor sampai saat permohonan ini diajukan tidak mungkin lagi membayar utang-utangnya karena usahanya telah tidak beroperasional, menunjukkan secara singkat telah dapat dibuktikan debitor berada dalam keadaan berhenti membayar utang-utangnya. Contoh pembuktian sederhana lainnya, harta kekayaan debitor sudah tidak mencukupi lagi untuk membayar utang-utangnya dan debitor sudah dalam keadaan berhenti membayar serta sebagian kreditor tidak berkeberatan

\footnotetext{
${ }_{9}$ Ridwan Khairandy, Pokok-Pokok Hukum Dagang Indonesia, Cetakan Ketiga, FH UII Press, Yogyakarta, 2017, hlm. 517
} 
debitor dinyatakan pailit. Dengan demikian, telah cukup bukti untuk menyatakan debitor dalam keadaan pailit. ${ }^{10}$

Berdasarkan Undang-Undang Nomor 4 Tahun 1998, fakta atau keadaan yang terbukti secara sederhana berkaitan dengan persyaratan permohonan pernyataan pailit, yaitu adanya dua kreditor atau lebih, debitor telah tidak membayar terhadap satu orang kreditornya, dan pembuktian terhadap adanya satu utang yang telah jatuh waktu dan dapat ditagih. Terhadap permohonan pernyataan pailit yang diajukan oleh kreditor, maka pembuktian mengenai hak tagih kreditor pun dilakukan secara sederhana. ${ }^{11}$ salah satu alasan penolakan terhadap permohonan pernyataan pailit pada masa berlakunya Undang-Undang Nomor 4 Tahun 1998 di Pengadilan Niaga karena pembuktiannya tidak sederhana, sebagai contohnya debitor menolak dan menyangkal alat bukti yang menunjukkan adanya empat lembar surat sanggup yang telah diendosemen sebagaimana mestinya sesuai dengan ketentuan undang-undang, karena penerbitannya cacat hukum. Penolakan dan penyangkalan tersebut menjadikan permasalahan ini belum bersifat pasti. Untuk menentukan keabsahannya memerlukan proses pembuktian yang tidak sederhana. Selain itu, suatu keadaaan memaksa membutuhkan pembuktian yang tidak sederhana dan harus melalui proses perdata biasa di peradilan umum. ${ }^{12}$

UU Kepailitan dan PKPU menentukan fakta atau keadaan yang terbukti secara sederhana apabila persyaratan untuk dinyatakan pailit telah terpenuhi. Persyaratan permohonan pernyataan pailit adalah debitor mempunyai dua atau lebih kreditor dan tidak membayar lunas sedikitnya satu utang yang telah jatuh waktu dan dapat ditagih. Fakta atau keadaan yang terbukti secara sederhana adalah adanya dua atau lebih kreditor dan fakta utang yang telah jatuh waktu dan tidak dibayar, dan debitor telah tidak membayar lunas terhadap satu orang kreditornya. Pelaksanaan perjanjian konsultan yang menimbulkan hak dan kewajiban bagi kedua belah pihak khususnya tagihan pembayaran hasil

\footnotetext{
10 Siti Anisah, Perlindungan kepentingan Kreditor dan Debitor Dalam Hukum Kepailitan di Indonesia, Cetakan Kedua, Total Media, Yogayakarta, 2008, hlm. 61

${ }^{11}$ Lihat penjelasan Pasal 6 ayat (3) Undang-Undang Nomor 4 Tahun 1998 tentang Penetapan Peraturan Pemerintah Pengganti Undang-Undang Nomor 1 Tahun 1998 tentang Perubahan atas Undang-Undang tentang Kepailitan menjadi Undang-Undang

12 Siti Anisah, Perlindungan Kepentingan Kreditor..., Op. Cit., hlm. 62
} 
pekerjaan masih membutuhkan penilaian yang lebih akurat, sehingga pembuktiannya tidak sederhana. Debitor dinyatakan pailit jika ia terbukti secara sederhana memenuhi persyaratan permohonan pernyataan pailit. Dalam beberapa putusan Pengadilan, permohonan pernyataan pailit dikategorikan sebagai pembuktian tidak sederhana, sehingga permohonan yang diajukan tidak dapat diterima, karena pembuktian tidak sederhana bukan merupakan kompetensi Pengadilan Niaga. ${ }^{13}$

Pengertian pembuktian secara sederhana lazim disebut sebagai pembuktian secara sumir. Bila permohonan pernyataan pailit diajukan oleh kreditor, pembuktian mengenai hak kreditor untuk menagih juga dilakukan secara sederhana. Dengan demikian, proses pemeriksaan permohonan kepailitan cukup dilakukan secara sederhana tanpa harus mengikuti atau terikat prosedur dan sistem pembuktian yang diatur di dalam hukum acara perdata. Karena pemeriksaan permohonan kepailitan bersifat sederhana, sikap aktif dari hakim amatlah diharapkan. Hakim diharapkan sedapat mungkin bisa mendengarkan kedua belah pihak (debitor dan kreditor) secara seksama di muka persidangan, serta berusaha mendamaikan keduanya. Dengan sikap seperti ini, jatuhnya putusan pailit pun dapat dihindari, dan ini akan menguntungkan kedua belah pihak, sebab sesungguhnya putusan kepailitan kurang dapat dipertanggungjawabkan dan berlarut-larut. ${ }^{14}$ Pembuktian sederhana dalam UU Kepailitan dan PKPU hanya diperuntukkan dalam permohonan pernyataan pailit. Sedangkan dalam PKPU, pembuktian sederhana tidak ditentukan apakah harus dengan pembuktian sederhana atau tidak.

UU Kepailitan dan PKPU tidak mendefinisikan pengertian dari Penundaan Kewajiban Pembayaran Utang (PKPU), namun beberapa pakar memberikan pengertian PKPU. Menurut Syamsudin M. Sinaga, PKPU adalah suatu masa tertentu yang diberikan oleh Pengadilan Niaga kepada debitor yang tidak dapat atau memperkirakan tidak akan dapat melanjutkan membayar utang-utangnya yang telah jatuh tempo dan dapat ditagih, untuk menegosiasikan cara pembayarannya kepada kreditor, baik sebagian maupun seluruhnya, termasuk merestrukturisasinya apabila dianggap perlu, dengan mengajukan rencana

\footnotetext{
${ }^{13}$ Ibid

${ }^{14}$ Susanti Adi Nugroho, Hukum Kepailitan di Indonesia Dalam Teori dan Praktik Serta Penerapan Hukumnya, Cetakan Pertama, Kencana, Jakarta, 2018, hlm. 55
} 
perdamaian yang meliputi tawaran pembayaran sebagian atau seluruh utangnya kepada kreditor. ${ }^{15}$ Menurut Munir Fuady, PKPU adalah suatu periode waktu tertentu yang diberikan oleh undang-undang melalui putusan Pengadilan Niaga, dalam periode waktu tersebut kepada kreditor dan debitor diberikan kesepakatan untuk memusyawarahkan cara-cara pembayaran utang-utangnya dengan memberikan rencana perdamaian (composition plan) terhadap seluruh atau sebagian utangnya itu, termasuk apabila perlu merestrukturisasi utangnya tersebut. Dengan kata lain PKPU merupakan semacam moratorium dalam hal ini legal moratorium. ${ }^{16}$ Menurut Kartini Muljadi, PKPU merupakan pemberian kesempatan kepada Debitor untuk melakukan restrukturisasi utang-utangnya, yang dapat meliputi pembayaran seluruh atau sebagian utang kepada kreditor konkuren. Jika hal tersebut belum dapat terlaksana denngan baik, pada akhirnya debitor dapat memenuhi kewajibannya dan meneruskan usahanya. ${ }^{17}$

PKPU dapat dilakukan sebagai upaya yang dilakukan debitor untuk menghindari kepailitan. Upaya tersebut hanya dapat diajukan oleh debitor sebelum putusan pernyataan pailit ditetapkan oleh pengadilan, karena berdasarkan Pasal 229 ayat (3) UU Kepailitan dan PKPU permohonan PKPU harus diputuskan lebih dahulu apabila permohonan pernyataan pailit dan permohonan PKPU diajukan pada waktu yang bersamaan. ${ }^{18}$ Jika permohonan PKPU diajukan setelah permohonan pernyataan pailit, maka berdasar Pasal 229 ayat (4) UU Kepailitan dan PKPU, permohonan PKPU wajib diajukan pada sidang pertama permohonan pernyataan pailit agar permohonan PKPU dapat diputus terlebih dahulu daripada permohonan pernyataan pailit. Di dalam pailit, harta kekayaan dan kewenangannya dikuasai oleh kurator sedangkan debitor tidak dapat menguasai harta kekayaannya dan tidak lagi berwenang melakukan perbuatan hukum berkaitan dengan harta kekayaannya. Sedangkan dalam PKPU, debitor tidak kehilangan penguasaan dan hak atas kekayaannya, hanya kehilangan kebebasan dalam penguasaan kekayaan, yaitu dibawah pengawasan

${ }^{15}$ Syamsudin M. Sinaga, Hukum Kepailitan di Indonesia, Cetakan Pertama, Tatanusa, Jakarta, 2012, hlm. 71

${ }^{16}$ Munir Fuady, Pengantar Hukum Bisnis, Cetakan Pertama, Citra Aditya Bakti, Bandung, 2001, hlm. 11

${ }^{17}$ Sutan Remy Sjahdeini, Sejarah, Asas, dan Teori Hukum Kepailitan Memahami Undang-Undang No. 37 Tahun 2004 tentang Kepailitan dan Penundaan Kewajiban Pembayaran Utang, Cetakan Kedua Edisi kedua, Kencana, Jakarta, 2018, hlm. 455

${ }^{18}$ Munir Fuady, Pengantar Hukum Bisnis, Op. Cit., hlm. 12 
pengurus dan hanya dapat bertindak atas izin pengurus, dengan kata lain debitor memiliki kewenangan dalam melakukan perbuatan hukum berkaitan dengan harta kekayaan berdasarkan izin pengurus.

PKPU dapat diajukan oleh debitor sendiri maupun oleh kreditornya. Ketentuan kreditor dapat mengajukan PKPU merupakan ketentuan baru dalam UU Kepailitan dan PKPU. Dalam Faillissementsverordening (Staatblad 1905 Nomor 217 juncto Staatblad 1906 Nomor 348) yang tetap berlaku sampai 1998, UndangUndang Nomor 4 Tahun 1998 tentang Penetapan Peraturan Pemerintah Pengganti Undang-Undang Nomor 1 Tahun 1998 tentang Perubahan atas Undang-Undang tentang Kepailitan menjadi Undang-Undang, hanya debitor saja yang dapat mengajukan. PKPU. Ketentuan kreditor juga dapat mengajukan PKPU merupakan ketentuan yang kurang tepat, karena filosofi PKPU adalah sebagai penyeimbang bagi debitor dalam menghadapi kepailitannya. Secara prinsip ada dua pola PKPU, yang pertama, PKPU yang merupakan tangkisan bagi debitor terhadap permohonan kepailitan yang diajukan oleh kreditornya. Kedua, PKPU atas inisiatif sendiri debitor yang memperkirakan ia tidak mampu membayar utang-utangnya kepada kreditor. Pasal 225 ayat (2) UU Kepailitan dan PKPU menyatakan bahwa dalam hal permohonan diajukan oleh debitor, pengadilan dalam waktu paling lambat 3 hari sejak tanggal didaftarkannya surat permohonan harus mengabulkan penundaan kewajiban pembayaran utang sementara dan harus menunjuk seorang hakim pengawas dari hakim pengadilan serta mengangkat 1 atau lebih pengurus yang bersama dengan debitor mengurus harta debitor. Sedangkan dalam hal permohonanan diajukan oleh kreditor, pengadilan dalan dalam waktu paling lambat 20 hari sejak tanggal didaftarkannya surat permohonan, harus mengabulkan permohonan penundaan kewajiban pembayaran utang sementara dan harus menunjuk hakim pengawas dari hakim pengadilan serta mengangkat 1 atau lebih pengurus yang bersama dengan debitor mengurus harta debitor.

Akibat hukum dari putusan putusan PKPU sementara bagi para kreditor adalah bahwa kreditor tidak dapat menagih utang-utangnya selama PKPU sementara tersebut karena debitor tidak diwajibkan untuk membayar utangutangnya. Sedangkan akibat hukum bagi debitor adalah bahwa dengan adanya 
PKPU tersebut, maka seluruh kekayaan debitor berada di bawah pengawasan pengurus, sehingga debitor tidak lagi berwenang terhadap harta kekayaannya untuk melakukan tindakan pengurusan maupun tindakan pengalihan tanpa persetujuan pengurus. Tindakan debitor terhadap kekayaannya tanpa persetu juan pengurus pada dasarnya tidak mengikat kekayaannya. ${ }^{19}$

Pasal 245 UU Kepailitan dan PKPU tentang pembayaran piutang masingmasing kreditor yang harus tunduk pada Pasal 185 ayat (3) UU Kepailitan dan PKPU, bahwa pembayaran utang tidak boleh dilakukan oleh kurator. Pembayaran semua utang yang sudah ada sebelum diberikannya PKPU atau selama berlangsungnya PKPU, tidak boleh dilakukan, kecuali pembayaran utang tersebut dilakukan kepada semua kreditor, menurut perimbangan piutang masing-masing, tanpa mengurangi berlakunya bahwa kurator wajib membayar piutang kreditor yang mempunyai hak untuk menahan suatu benda, sehingga benda itu masuk kembali dan menguntungkan harta pailit.

Pasal 246 UU Kepailitan dan PKPU yang menyatakan ketentuan Pasal 56, 57 dan 58 UU Kepailitan dan PKPU berlaku mutatis mutandis terhadap pelaksanaan kreditor sebagaimana dimaksud dalam Pasal 55 ayat (1) UU Kepailitan dan PKPU, artinya mengenai hak eksekusi dalam putusan pernyataan pailit berlaku juga dalam putusan PKPU. Hak eksekusi kreditor dan hak pihak ketiga untuk menuntut hartanya yang berada dalam penguasaan debitor atau kurator, ditangguhkan. Penangguhan tersebut tidak berlaku terhadap tagihan kreditor yang dijamin dengan uang tunai dan hak kreditor untuk memperjumpaan utang. Selama jangka waktu penangguhan kurator dapat menggunakan harta pailit berupa benda tidak bergerak maupun benda bergerak atau menjual harta pailit yang berupa benda bergerak yang berada dalam penguasaan kurator dalam rangka kelangsungan usaha debitor, dalam hal telah diberikan perlindungan yang wajar bagi kepentingan kreditor atau pihak ketiga. Jangka waktu tersebut dapat dipercepat apabila ditemukan keadaan insolvensi.20

Pasal 248 ayat (3) UU Kepailitan dan PKPU yang menyatakan Pasal 53 dan 54 UU Kepailitan dan PKPU berlaku bagi perjumpaan utang pada PKPU. Setiap hlm. 322

19 M. Hadi Shubhan, Prinsip, Norma, dan Praktik di Peradilan, Cetakan Pertama, Kencana, Jakarta, 2015, ${ }^{20}$ Lihat ketentuan Pasal 246 UU Kepailitan dan PKPU 
orang yang mempunyai utang kepada debitor pailit, yang hendak menjumpakan utangnya dengan suatu piutang atas tunjuk atau piutang atas pengganti, wajib membuktikan bahwa pada saat putusan pernyataan pailit diucapkan, orang tersebut dengan iktikad baik sudah menjadi pemilik surat atas tunjuk atau surat atas pengganti tersebut. Selain itu, setiap orang yang dengan debitor berada dalam suatu persekutuan berhak untuk mengurangi bagian dari keuntungannya yang pada waktu pembagian diadakan jatuh kepada debitor, dengan kewajiban debitor untuk membayar utang persekutuan. ${ }^{21}$

Pasal 256 UU Kepailitan dan PKPU yang menyatakan Pasal 11, 12, 13, 14 UU Kepailitan dan PKPU berlaku mutatis mutandis terhadap putusan pernyataan pailit sebagai akibat putusan pengakhiran PKPU. Upaya hukum yang dapat diajuan terhadap putusan PKPU adalah kasasi ke Mahkamah Agung. Permohonan kasasi diajukan paling lambat 8 hari setalah putusan yang dimohonkan kasasi diucapkan. Permohonan kasasi tersebut selain dapat diajukan oleh debitor dan kreditor yang merupakan pihak dalam persidangan, juga dapat dimohonkan oleh kreditor lain yang bukan merupakan pihak dalam persidangan yang tidak puas terhadap putusan tersebut. Panitera mendaftar permohonan kasasi pada tanggal permohonan yang bersangkutan diajukan dan kepada pemohon diberikan tanda terima tertulis yang ditandatangani panitera dengan tanggal yang sama dengan tanggal penerimaan pendaftaran. Pemohon kasasi wajib menyampaikan kepada Panitera Pengadilan memori kasasi pada tanggal permohonan kasasi didaftarkan. Panitera wajib mengirimkan permohonan kasasi dan memori kasasi kepada pihak termohon kasasi paling lambat 2 hari setelah permohonan kasasi didaftarkan. Termohon kasasi dapat mengajukan kontra memori kasasi kepada panitera Pengadilan paling lambat 7 hari setelah tanggal termohon kasasi menerima memori kasasi dan panitera Pengadilan wajib menyampaikan kontra memori kasasi kepada pemohon kasasi paling lambat 2 hari setelah kontra memori kasasi diterima. Panitera wajib menyampaikan permohonan kasasi, memori kasasi, dan kontra memori kasasi beserta berkas perkara yang bersangkutan kepada Mahkamah Agung paling lambat 14 hari setelah tanggal permohonan kasasi didaftarkan. ${ }^{22}$

\footnotetext{
${ }^{21}$ Lihat ketentuan Pasal 248 ayat (3) UU Kepailitan dan PKPU

${ }^{22}$ Lihat ketentuan Pasal 256 UU Kepailitan dan PKPU
} 
Mahkamah Agung wajib mempelajari permohonan kasasi dan menetapkan hari sidang paling lambat 2 hari setelah tanggal permohonan kasasi diterima oleh Mahkamah Agung. Sidang pemeriksaan atas permohonan kasasi dilakukan paling lambat 20 hari setelah tanggal permohonan kasasi diterima oleh Mahkamah Agung. Putusan atas permohonan kasasi harus diucapkan paling lambat 60 hari setelah tanggal permohonan kasasi diterima oleh Mahkamah Agung. Putusan permohonan kasasi yang memuat secara lengkap pertimbangan hukum yang mendasari putusan tersebut harus diucapkan dalam sidang terbuka untuk umum. Dalam hal terdapat perbedaan pendapat antara anggota dengan ketua majelis maka perbedaan pendapat tersebut wajib dimuat dalam putusan kasasi. Panitera pada Mahkamah Agung wajib menyampaikan salinan putusan kasasi kepada Panitera pada Pengadilan Niaga paling lambat 3 hari setelah tanggal putusan atas permohonan kasasi diucapkan. Jurusita Pengadilan wajib menyampaikan salinan putusan kasasi sebagaimana dimaksud pada ayat (5) kepada pemohon kasasi, termohon kasasi, Kurator, dan Hakim Pengawas paling lambat 2 hari setelah putusan kasasi diterima. Terhadap putusan, atas permohonan pernyataan pailit yang telah memperoleh kekuatan hukum tetap, dapat diajukan peninjauan kembali ke Mahkamah Agung. ${ }^{23}$

Berdasarkan hal tersebut, maka ketentuan dalam pernyataan pailit yang berlaku dalam putusan PKPU hanya yang terdapat dalam pasal-pasal di atas. Pembuktian sederhana yang terdapat dalam Pasal 8 ayat (4) jo Pasal 2 ayat (1) UU Kepailitan dan PKPU yang mengatur pembuktian sederhana berlaku terhadap permohonan pernyataan pailit, sedangkan dalam permohonan PKPU, sebenarnya UU Kepailitan dan PKPU tidak megharuskan penerapan pembuktian sederhana yang menyatakan bahwa permohonan pernyataan pailit harus dikabulkan apabila terdapat fakta atau keadaan yang terbukti secara sederhana bahwa persyaratan untuk dinyatakan pailit sebagaiamana dimaksud dalam Pasal 2 ayat (1) UU Kepailitan dan PKPU telah terpenuhi. Jadi meskipun telah terbukti secara sederhana, tidak serta merta hakim akan memutuskan PKPU terhadap debitor. Berdasarkan UU Kepailitan dan PKPU, jika telah terbukti secara sederhana dapat dinyatakan pailit, permohonan PKPU tidak wajib dikabulkan. Namun 
berdasarkan Pasal 225 ayat (2) UU Kepailitan dan PKPU, terhadap permohonan PKPU yang diajukan debitor pengadilan wajib mengabulkan permohonan PKPU sementara dan harus menunjuk seorang Hakim Pengawas dari hakim pengadilan dan mengangkat pengurus bersama debitor mengurus harta debitor. ${ }^{24}$

Terhadap permohonan PKPU yang diajukan ke pengadilan, hakim wajib mengabulkan permohonan PKPU sementara tanpa melihat pembuktiannya. Pembuktian sederhana seperti dalam permohonan kepailitan tidak berlaku dalam permohonan PKPU, karena berdasarkan Pasal 225 ayat (2) UU Kepailitan dan PKPU, hakim wajib mengabulkan permohonan PKPU sementara tanpa melihat bahwa pembuktiannya merupakan pembuktian sederhana atau tidak. Hakim tidak wajib tunduk pada ketentuan yang terdapat dalam UU Kepalitan dan PKPU karena di dalamnya tidak memuat ketentuan mengenai pembuktian sederhana dalam permohonan PKPU. Setelah mendapatkan putusan PKPU sementara maka debitor akan mengajukan rencana perdamaian. Dengan rencana perdamaian itu diharapkan permasalahan yang dihadapi kreditor dan debitor dapat diselesaikan tanpa proses permohonan kepailitan. Setelah itu, kreditor akan memberikan suara apakah menolak atau menerima PKPU tetap, jika kreditor menolak adanya PKPU tetap, maka debitor akan dinyatakan pailit. Jika PKPU tetap dapat disepakati oleh kreditor dan debitor, maka pemberian PKPU tetap akan ditentukan oleh pengadilan. Hal tersebut juga harus memeperhatikan Surat Keputusan Ketua Mahkamah Agung (SKMA) Nomor 109/KMA/SK/IV/2020 tentang Pemberlakuan Buku Pedoman Penyelesaian Perkara Kepailitan dan Penundaan Kewajiban Pembayaran Utang. ${ }^{25}$

Beberapa putusan hakim mengenai PKPU, tidak jarang hakim menggunakan pembuktian sederhana sebagai syarat penjatuhan putusan PKPU, seperti dalam putusan Mahkamah Agung Republik Indonesia Nomor 586 K/Pdt.Sus-Pailit/2013, dalam putusannya Hakim menolak permohonan PKPU dengan pertimbangan pembuktian yang tidak sederhana dengan dasar ketentuan

${ }^{24}$ Lihat ketentuan Pasal 8 ayat (4) jo Pasal 2 ayat (1) UU Kepailitan dan PKPU dan Pasal 225 ayat (2) UU Kepailitan dan PKPU

${ }^{25}$ Lihat Surat Keputusan Ketua Mahkamah Agung (SKMA) Nomor 109/KMA/SK/IV/2020 tentang Pemberlakuan Buku Pedoman Penyelesaian Perkara Kepailitan dan Penundaan Kewajiban Pembayaran Utang 
Pasal 8 ayat (4) jo Pasal 2 ayat (1) UU Kepailitan dan PKPU. ${ }^{26}$ Namun sebaliknya, ada beberapa putusan hakim yang tidak menggunakan pembuktian sederhana sebagai syarat penjatuhan putusan PKPU, seperti Putusan No. 48/PAILIT/ 2012/PN.NIAGA/JKT.PST tentang PT Telekomunikasi Selular Tbk., Putusan No. 10/Pailit/2002/PN.Niaga.JKT tentang PT Asuransi Jiwa Manulife Indonesia, Putusan No. 13/Pailit/2004/PN.Niaga.JKS.PST tentang PT Prudential Life Assurance yang memutuskan PKPU tanpa melihat pembuktian sederhana.

\section{Perbandingan Konsep Pembuktian Sederhana dalam Kepailitan dan Penundaan Kewajiban Pembayaran Utang (PKPU)}

Kepailitan merupakan salah satu cara menyelesaikan utang piutang. Berbeda dengan gugatan wanprestasi (perdata umum) yang hanya perlu satu orang kreditor, kepailitan bukan untuk penyelesaian utang untuk seorang kreditor, tapi untuk sejumlah orang kreditor (minimal dua orang kreditur). Perkara kepailitan diputus paling lama 60 hari sejak didaftarkan di pengadilan niaga, sedangkan untuk perkara perdata umum bisa relatif lebih lama. Tidak dikenal upaya hukum banding pada perkara kepailitan. Setelah diputus oleh pengadilan niaga (tingkat pertama) pihak yang tidak puas dengan putusan tersebut dapat mengajukan kasasi ke Mahkamah Agung. Waktu penyelesaian perkara kepailitan di Mahkamah Agung sama seperti tingkat pertama yakni 60 hari sejak berkas perkara di terima di Mahkamah Agung. ${ }^{27}$

Pailit merupakan suatu keadaan di mana debitor tidak mampu untuk melakukan pembayaran-pembayaran terhadap utang-utang dari para kreditornya. Keadaan tidak mampu membayar lazimnya disebabkan karena kesulitan kondisi keuangan (financial distress) dari usaha debitor yang telah mengalami kemunduran. Sedangkan, kepailitan merupakan putusan pengadilan yang mengakibatkan sita umum atas seluruh kekayaan debitor pailit, baik yang telah ada maupun yang akan ada di kemudian hari. Pengurusan dan pemberesan kepailitan dilakukan oleh kurator di bawah pengawasan hakim pengawas dengan tujuan utama menggunakan hasil penjualan harta kekayaan tersebut untuk

${ }^{26}$ Lihat putusan Mahkamah Agung Republik Indonesia Nomor 586 K/Pdt.Sus-Pailit/2013

27 Boris Tampubolon, Mekanisme Kepailitan Sebagai Cara menagih Utang, Terdapat dalam http://konsultanhukum.web.id/mekanisme-kepailitan-sebagai-cara-menagih-utang/, diakses pada 14 Oktober 2020, pukul 15.47 WIB. 
membayar seluruh utang debitor pailit tersebut secara proporsional (prorate parte) dan sesuai dengan struktur kreditor. ${ }^{28}$

Ada beberapa faktor perlunya pengaturan mengenai kepailitan dan penundaan kewajiban pembayaran utang yaitu untuk menghindari adanya perebutan harta debitor apabila dalam waktu yang sama ada beberapa kreditor yang menagih piutangnya dari debitor; kreditor pemegang hak jaminan kebendaan yang menuntut haknya dengan cara menjual barang milik debitor tanpa memperhatikan kepentingan debitor atau para kreditor; dan kecurangankecurangan yang dilakukan oleh salah satu kreditor atau debitor sendiri. Kepailitan merupakan suatu jalan keluar untuk dapat keluar dari persoalan utang piutang yang menghimpit seorang debitor, dimana debitor tersebut sudah tidak mempunyai kemampuan lagi untuk membayar utang-utang tersebut kepada para kreditornya. Apabila ketidakmampuan untuk membayar utang yang telah jatuh tempo disadari oleh debitor, maka langkah yang dapat diambil oleh debitor ialah dengan mengajukan permohonan penetapan status pailit terhadap dirinya sendiri, atau dengan cara penetapan status pailit yang dikeluarkan oleh pengadilan apabila telah terbukti bahwa debitor tersebut memang telah tidak mampu lagi untuk membayar utangnya yang telah jatuh tempo dan dapat ditagih. ${ }^{29}$

Merujuk pada Pasal 8 ayat (4) UU Kepailitan dan PKPU bahwa yang harus dibuktikan secara sederhana adalah syarat kepailitan dalam Pasal 2 ayat (1) UU Kepailitan dna PKPU, yaitu: ${ }^{30}$

a. Ada 2 (dua) atau lebih kreditor. Kreditor adalah orang yang mempunyai piutang karena perjanjian atau undang-undang yang dapat ditagih di muka pengadilan. Kreditor di sini mencakup baik kreditor konkuren, kreditor separatis maupun kreditor preferen.

b. Ada utang yang telah jatuh waktu dan dapat ditagih yang tidak dibayar lunas oleh debitor. Artinya adalah ada kewajiban untuk membayar utang yang telah jatuh waktu, baik karena telah diperjanjikan, karena percepatan waktu penagihannya sebagaimana diperjanjikan, karena pengenaan sanksi atau denda oleh instansi yang berwenang, maupun karena putusan pengadilan, arbiter, atau majelis arbitrase.

28 Iwan Sidharta, "Pembuktian Sederhana Dalam Putusan Pailit (Studi Kasus Perkara nomor 515K/Pdt.Sus/2016)”, Jurnal Legal Reasong, Vol. 1, No. 1, Desember 2018, hlm. 42

${ }^{29}$ Doni Budiono, "Analisis Pengaturan Hukum Acara Kepailitan dan Penundaan Kewajiban Pembayaran Utang", Jurnal Hukum Acara Perdata, op.cit, hlm. 118

${ }^{30}$ Iwan Sidharta, Pembuktian Sederhana..., Op. Cit., hlm. 43 
Prinsip pembuktian tersebut maka hakim wajib memberikan beban pembuktian kepada penggugat untuk membuktikan dalil atau peristiwa yang dapat mendukung dalil tersebut, yang diajukan oleh penggugat, sedangkan bagi tergugat, hakim wajib memberikan suatu beban pembuktian untuk membuktikan bantahannya atas dalil yang diajukan oleh para penggugat. Hakim hendaknya tidak begitu saja secara harfiah melaksanakan asas pembuktian, tetapi hakim harus bijaksana dan pantas, yaitu hendaknya hakim meletakkan keharusan membuktikan kepada pihak yang paling gampang untuk membuktikan, dan tidak membebani kepada pihak yang paling sulit untuk membuktikan, terkhusus pada perkara yang didasarkan pada suatu hubungan hukum yang timbul tanpa adanya alat bukti tulisan atau surat (dilakukan secara lisan) oleh para pihak. ${ }^{31}$

Pembuktian sederhana yang terdapat dalam Pasal Pasal 8 ayat (4) jo Pasal 2 ayat (1) UU Kepailitan dan PKPU yang mengatur pembuktian sederhana berlaku terhadap permohonan pernyataan pailit, sedangkan dalam permohonan PKPU, sebenarnya UU Kepailitan dan PKPU tidak megharuskan penerapan pembuktian sederhana yang menyatakan bahwa permohonan pernyataan pailit harus dikabulkan apabila terdapat fakta atau keadaan yang terbukti secara sederhana bahwa persyaratan untuk dinyatakan pailit sebagaiamana dimaksud dalam Pasal 2 ayat (1) UU Kepailitan dan PKPU telah terpenuhi. Namun dalam Pasal 225 ayat (2) UU Kepailitan dan PKPU menyatakan bahwa permohonan PKPU (sementara) harus dikabulkan paling lambat 3 hari sejak didaftarkan. Hal tersebut memberikan ketidakpastian hukum, karena hakim menjadi tidak berhak untuk menolak PKPU tersebut.

Terhadap permohonan PKPU yang diajukan ke pengadilan, hakim wajib mengabulkan permohonan PKPU sementara tanpa melihat pembuktiannya. Pembuktian sederhana seperti dalam permohonan kepailitan tidak berlaku dalam permohonan PKPU, karena berdasarkan Pasal 225 ayat (2) UU Kepailitan dan PKPU, hakim wajib mengabulkan permohonan PKPU sementara tanpa melihat bahwa pembuktiannya merupakan pembuktian sederhana atau tidak. Hakim tidak wajib tunduk pada ketentuan yang terdapat dalam UU Kepalitan dan PKPU karena di dalamnya tidak memuat ketentuan mengenai pembuktian sederhana dalam

${ }_{11}$ Nelson Kapoyos, Konsep Pembuktian Sederhana dalam Perkara Kepailitan Kajian Putusan Nomor 125 PK/PDT.SUS-PAILIT/2015, Jurnal Yudisial, Vol. 10. No. 3, Desember 2017, hlm. 340 
permohonan PKPU. Setelah mendapatkan putusan PKPU sementara maka debitor akan mengajukan rencana perdamaian. Dengan rencana perdamaian itu diharapkan permasalahan yang dihadapi kreditor dan debitor dapat diselesaikan tanpa proses permohonan kepailitan. Setelah itu, kreditor akan memberikan suara apakah menolak atau menerima PKPU tetap, jika kreditor menolak adanya PKPU tetap, maka debitor akan dinyatakan pailit. Jika PKPU tetap dapat disepakati oleh kreditor dan debitor, maka pemberian PKPU tetap akan ditentukan oleh pengadilan. ${ }^{32}$

Berdasarkan paparan di atas, dapat diketahui bahwa dalam permohonan kepailitan, hakim wajib mengabulkan jika terbukti secara sederhana bahwa debitor mempunyai dua atau lebih kreditor dan tidak membayar lunas sedikitnya satu utang yang telah jatuh waktu dan dapat ditagih, dinyatakan pailit dengan putusan Pengadilan. Hal tersebut tercantum dalam Pasal 8 ayat (4) jo Pasal 2 ayat (1) UU Kepailitan dan PKPU. Sedangkan dalam permohonan PKPU, asas pembuktian sederhana tidak diharuskan untuk dipernuhi oleh pemohon PKPU. Hakim tidak wajib untuk melaksanakan pemberlakukan pembuktian sederhana dalam permohonan PKPU, dengan kata lain bahwa hakim tidak tunduk dalam asas pembuktian sederhana seperti dalam permohonan kepailitan. Secara ringkas, Perbandingan Konsep Pembuktian Sederhana dalam Kepailitan dan Penundaan Kewajiban Pembayaran Utang (PKPU) dapat dilihat dalam tabel berikut ini:

\begin{tabular}{|c|c|c|}
\hline $\begin{array}{l}\text { Sesuatu yang } \\
\text { dibandingkan }\end{array}$ & Kepailitan & PKPU \\
\hline $\begin{array}{l}\text { Pasal yang } \\
\text { mengatur }\end{array}$ & $\begin{array}{l}\text { Pasal } 8 \text { ayat (4) jo Pasal } 2 \\
\text { ayat (1) UU Kepailitan dan } \\
\text { PKPU }\end{array}$ & $\begin{array}{l}\text { Pasal } 225 \text { ayat (2) UU Kepailitan } \\
\text { dan PKPU }\end{array}$ \\
\hline $\begin{array}{l}\text { Konsep } \\
\text { Pembuktian } \\
\text { Sederhana }\end{array}$ & $\begin{array}{l}\text { Harus dibuktikan secara } \\
\text { sederhana dengan syarat } \\
\text { kepailitan dalam Pasal } 2 \text { ayat } \\
\text { (1) UU Kepailitan dan PKPU } \\
\text { yaitu: ada } 2 \text { (dua) atau lebih } \\
\text { kreditor dan ada utang yang } \\
\text { telah jatuh waktu dan dapat } \\
\text { ditagih yang tidak dibayar } \\
\text { lunas oleh debitor. }\end{array}$ & $\begin{array}{l}\text { Permohonan PKPU, sebenarnya } \\
\text { UU Kepailitan dan PKPU tidak } \\
\text { megharuskan penerapan } \\
\text { pembuktian sederhana. Pasal } \\
225 \text { ayat (2) UU Kepailitan dan } \\
\text { PKPU menyatakan bahwa } \\
\text { permohonan PKPU (sementara) } \\
\text { harus dikabulkan paling lambat } \\
3 \text { (tiga) hari sejak didaftarkan, } \\
\text { jadi hakim menjadi tidak berhak } \\
\text { untuk menolak PKPU tersebut. }\end{array}$ \\
\hline
\end{tabular}

${ }^{32}$ Lihat ketentuan Pasal Pasal 225 ayat (2) UU Kepailitan dan PKPU 


\begin{tabular}{lll}
\hline $\begin{array}{l}\text { Penerapan } \\
\begin{array}{l}\text { Pembuktian } \\
\text { Sederhana }\end{array}\end{array}$ & $\begin{array}{l}\text { Wajib diterapkan apabila } \\
\text { terbukti secara sederhana }\end{array}$ & $\begin{array}{l}\text { Tidak wajib menerapkan } \\
\text { pembuktian sederhana }\end{array}$ \\
\hline
\end{tabular}

Meskipun UU kepailitan dan PKPU tidak mengatur asas pembuktian secara sederhana dapat diterapkan dalam permohonan PKPU namun hakim pada dasarnya dapat menerapkan asas pembuktian sederhana tersebut dengan memperhatikan asas peradilan sederhana, cepat, dan biaya ringan serta tujuan dari UU kepailitan dan PKPU yaitu agar perkara kepailitan dan PKPU dapat terselenggara secara cepat, adil, dan terbuka maka asas pembuktian sederhana dapat juga diterapkan dalam permohonan PKPU. Akan lebih baik apabila hakim dalam menerapkan pembuktian secara sederhana dalam permohonan PKPU dengan menggunakan Pasal 8 ayat (4) UU Kepailitan dan PKPU juga menggunakan asas peradilan sederhana, cepat, dan biaya ringan seperti yang diatur dalam Pasal 4 ayat (2) Undang-Undang Nomor 48 Tahun 2009 tentang Kekuasaan Kehakiman serta mengacu pada tujuan UU Kepailitan dan PKPU yaitu agar perkara kepailitan dan PKPU dapat diselesaikan dengan lebih cepat, adil, dan terbuka sebagai pertimbagannya.

\section{Penutup}

Berdasarkan analisis di atas, dapat disimpulkan bahwa, pertama, pembuktian sederhana yang terdapat dalam Pasal 8 ayat (4) jo Pasal 2 ayat (1) UU Kepailitan dan PKPU yang mengatur pembuktian sederhana berlaku terhadap permohonan pernyataan pailit, sedangkan dalam permohonan PKPU, sebenarnya UU Kepailitan dan PKPU tidak megharuskan penerapan pembuktian sederhana yang menyatakan bahwa permohonan pernyataan pailit harus dikabulkan apabila terdapat fakta atau keadaan yang terbukti secara sederhana bahwa persyaratan untuk dinyatakan pailit sebagaiamana dimaksud dalam Pasal 2 ayat (1) UU Kepailitan dan PKPU telah terpenuhi. Jadi meskipun telah terbukti secara sederhana, tidak serta merta hakim akan memutuskan PKPU terhadap debitor. Berdasarkan UU Kepailitan dan PKPU, jika telah terbukti secara sederhana dapat dinyatakan pailit, permohonan PKPU tidak wajib dikabulkan. Namun berdasarkan Pasal 225 ayat (2) UU Kepailitan dan PKPU, terhadap permohonan 
PKPU yang diajukan debitor pengadilan wajib mengabulkan permohonan PKPU sementara dan harus menunjuk seorang Hakim Pengawas dari hakim pengadilan dan mengangkat pengurus bersama debitor mengurus harta debitor.

Kedua, meskipun UU kepailitan dan PKPU tidak mengatur asas pembuktian secara sederhana dapat diterapkan dalam permohonan PKPU namun hakim pada dasarnya dapat menerapkan asas pembuktian sederhana tersebut dengan memperhatikan asas peradilan sederhana, cepat, dan biaya ringan seperti yang diatur dalam Pasal 4 ayat (2) Undang-Undang Nomor 48 Tahun 2009 tentang Kekuasaan Kehakiman serta mengacu pada tujuan UU Kepailitan dan PKPU yaitu agar perkara kepailitan dan PKPU dapat diselesaikan dengan lebih cepat, adil, dan terbuka sebagai pertimbagannya. Serta tujuan dari UU kepailitan dan PKPU yaitu agar perkara kepailitan dan PKPU dapat terselenggara secara cepat, adil, dan terbuka maka asas pembuktian sederhana dapat juga diterapkan dalam permohonan PKPU.

\section{Daftar Pustaka}

\section{Buku}

Adi Nugroho, Susanti, Hukum Kepailitan di Indonesia Dalam Teori dan Praktik Serta Penerapan Hukumnya, Cetakan Pertama, Kencana, Jakarta, 2018.

Anisah, Siti, Perlindungan kepentingan Kreditor dan Debitor Dalam Hukum Kepailitan di Indonesia, Cetakan Kedua, Total Media, Yogayakarta, 2008.

Fuady, Munir, Pengantar Hukum Bisnis, Cetakan Pertama, Citra Aditya Bakti, Bandung, 2001.

Hartini, Rahayu, Hukum Kepailitan, Cetakan Pertama, UMM Press, Malang, 2007.

Khairandy, Ridwan, Pokok-Pokok hukum Dagang Indonesia, Cetakan Ketiga, FH UII Press, Yogyakarta, 2017.

M. Sinaga, Syamsudin, Hukum Kepailitan di Indonesia, Cetakan Pertama, Tatanusa, Jakarta, 2012.

Ras Ginting, Elyta, Hukum Kepailitan: Teori Kepailitan, Cetakan Pertama, Sinar Grafika, Jakarta, 2018.

Remy Sjahdeini, Sutan, Sejarah, Asas, dan Teori Hukum Kepailitan Memahami Undang-Undang No. 37 Tahun 2004 tentang Kepailitan dan Penundaan Kewajiban Pembayaran Utang. Cetakan Kedua Edisi kedua, Kencana, Jakarta, 2018.

Shubhan, M. Hadi, Prinsip, Norma, dan Praktik di Peradilan, Cetakan Pertama, Kencana, Jakarta, 2015. 
Suyatno, R. Anton, Pemanfaatan Penundaan Kewajiban Pembayaran Utang Sebagai Upaya Mencegah Kepailitan, Cetakan Pertama, Kencana Prenada Media Group, Jakarta, 2012.

\section{Hasil Penelitian}

Amelia, “Tinjauan Yuridis Terhadap Pembatalan Putusan Pailit Atas Perusahaan Asuransi (Studi Kasus PT Prudential Life Assurance melawan Lee Roon Siong)", Tesis, Universitas Tarumanegara, 2018

\section{Jurnal}

Chaula Rahayu, Annisa Herman Susetyo, Paramita Prananingtyas, "Putusan Pailit Atas Perusahaan Asuransi dan Akibat Hukumnya di Indonesia (Kajian Yuridis Atas Putusan No. 10/Pailit/2002/PN.JKT.PST dan Putusan MA No. 021 /K/N/2002", Jurnal Diponegoro Law Review, Vol 1, No. 2, 2013

Doni Budiono, “Analisis Pengaturan Hukum Acara Kepailitan dan Penundaan Kewajiban Pembayaran Utang", Jurnal Hukum Acara Perdata, Vol. 4, No. 2, Juli-Desember 2018

Iwan Sidharta, "Pembuktian Sederhana Dalam Putusan Pailit (Studi Kasus Perkara nomor 515K/Pdt.Sus/2016)", Jurnal Legal Reasong, Vol. 1, No. 1, Desember 2018.

Maruli Simalago, "Inkonsistensi Persyaratan Permohonan Pailit Dihubungkan dengan Asas Kelangsungan Usaha (Going Concern) dalam UndangUndang No. 37 Tahun 2004 tentang Kepailitan dan Penundaan Kewajiban Pembayaran Utang", Jurnal Syiar Hukum, Vol. 15, No. 1, Juni 2017

Nelson Kapoyos, "Konsep Pembuktian Sederhana dalam Perkara Kepailitan Kajian Putusan Nomor 125 PK/PDT.SUS-PAILIT/2015", Jurnal Yudisial, Vol. 10. No. 3, Desember 2017

\section{Internet}

Tampubolon, Boris Mekanisme Kepailitan Sebagai Cara menagih Utang, Terdapat dalam http:/ / konsultanhukum.web.id/mekanisme-kepailitan-sebagai-caramenagih-utang/, diakses pada tanggal 14 Oktober 2020, pukul 15.47 WIB.

\section{Peraturan Perundang-Undangan}

Undang-Undang Nomor 37 Tahun 2004 tentang Kepailitan dan Penundaan Kewajiban Pembayaran Utang.

Undang-Undang Nomor 4 Tahun 1998 tentang Penetapan Peraturan Pemerintah Pengganti Undang-Undang Nomor 1 Tahun 1998 tentang Perubahan atas Undang-Undang tentang Kepailitan menjadi Undang-Undang.

Surat Keputusan Ketua Mahkamah Agung (SKMA) Nomor 109/KMA/SK/IV/2020 tentang Pemberlakuan Buku Pedoman Penyelesaian Perkara Kepailitan dan Penundaan Kewajiban Pembayaran Utang. 


\section{Putusan Pengadilan}

Putusan No. 48/PAILIT/2012/PN.NIAGA/JKT.PST pada tanggal 14 September 2012 tentang pailit PT terhadapTelekomunikasi Selular Tbk. Yang diajukan oleh PT. Prima Jaya Informatika

Putusan No. 10/Pailit/2002/PN.Niaga.JKT pada tanggal 13 Juni 2000 tentang pailit terhadap PT Asuransi Jiwa Manulife Indonesia yang dimohonkan oleh PT Dharmala Sakti Sejahtera

Putusan No.13/Pailit/2004/PN.Niaga.JKS.PST pada tanggal 23 April 2004 tentang pailit terhadap PT Prudential Life Assurance yang dimohonkan oleh Lee Boon Siong

Putusan Mahkamah Agung Republik Indonesia Nomor 586 K/Pdt.SusPailit/2013 antara PT Ohana Mandiri Sejahtera melawan Cv Surya Perdana Motor 